\title{
MEASURING THE TECHNOLOGY ACHIEVEMENT INDEX: COMPARISON AND RANKING OF COUNTRIES
}

\author{
DOI: 10.17261/Pressacademia.2017.446 \\ JEFA- V.4-ISS.2-2017(11)-p.164-174
}

\author{
Ahmet Incekara ${ }^{1}$, Tugba Guz ${ }^{3}$, Gulden Sengun ${ }^{2}$ \\ ${ }^{1}$ Istanbul University, Istanbul, Turkey. incekara@istanbul.edu.tr \\ ${ }^{2}$ Istanbul University, Istanbul, Turkey. sengungulden@gmail.com \\ ${ }^{3}$ Istanbul University, Istanbul, Turkey. tugbaguz@gmail.com
}

To cite this document

Incekara, A., T. Guz and G. Sengun, (2017). Measuring the technology achievement index: comparison and ranking of countries. Journal of Economics, Finance and Accounting (JEFA), V.4, Iss.2, p.164-174

Permemant link to this document: http://doi.org/10.17261/Pressacademia.2017.446

Copyright: Published by PressAcademia and limited licenced re-use rights only.

\begin{abstract}
Purpose- Countries that can adapt to the pace of technological developments, follow and use this speed have a stronger economy and obtain a significant competitive advantage in the global arena. Therefore, the countries make various regulations to increase the technological achievements, access to the global technologies, adapt to the rapid technological transformation and organize their substructures according to these technologies. Technology Achievement Index (TAI), which is one of the studies to evaluate the technological performance of countries, classifies countries according to their technological achievements.

Methodology- In this study, TAI-16 of 105 countries is calculated by using the methodology based on the original study of Desai et al. TAI that originally proposed in 2002 by Desai et al. is a unified index that revealing countries' technological abilities and performance in terms of technology capacity, diffusion of new technologies, diffusion of old innovations and development of human skills. TAl which consists of four main dimensions and eight sub-indicators of the dimensions calculate the average of the dimensions of the index based on the selected indicators. Each of four dimensions includes two sub-indicators.

Findings- In this study, technological capabilities and performances of 105 countries were analyzed and Technology Achievement Index (TAI-16) was calculated using most of the data of 2015. Moreover, TAl-16 values of the 105 countries were classified as Leaders (TAI > 0,5), Potential Leaders (TAI =0,35-0,49), Dynamic Adopters (TAI =0,20-0,34), and Marginalized (TAI <0,20) following the methodology in TAI-02. Conclusion- According to TAl-16 classification, the countries were identified as follows; 40 countries as Leaders, 38 countries as Potential Leaders, 17 countries as Dynamic Adopters, and 10 countries as Marginalized. Furthermore, TAI ranking of the 105 countries was created. In this classification, while Switzerland had the highest with 0.813 TAl value, Ethiopia had the lowest value with 0,028 TAI value.
\end{abstract}

Keywords: Human skills, technology achievement index, technology creation, technology development, technology diffusion. JEL Codes: 031, 033, 034

\section{INTRODUCTION}

The factors such as technology achievement capacity, creativity, diffusion of innovation, and knowledge generation have become fundamental conditions to provide the sustainable competitive advantage, economic growth, and development in the global arena. In this process, countries make various regulations to increase the technological achievements, access to the global technologies, adapt to the rapid technological transformation and organize their sub-structures according to these technologies.

Countries benefit from global technological advantages when they increase their technological capacities and performances. There are many factors that influence the technological achievement and progress in a country, as well as several methods used to measure this success. Human Development Index (HDI), ICT Development Index (IDI) reported by 
ITU, Global Competitiveness Report (GCR) reported by World Economic Forum, The Global Information Technology Report, Global Innovation Index (GII), and Technology Achievement Index (TAI) are one of these methods.

Technology Achievement Index (TAI) is a composite index that measures of the countries' skills to participate in the network age. The TAI was included in Human Development Index 2001 and originally developed by Desai et al. It reflects countries' ability to create and diffuse technology as well as building human skills.

The TAl evaluates the technological performance of countries and classifies the countries according to their technological achievements but not measure the overall size of their technological development. (Nasir et al. 2011). It focuses on the countries technological performances based on their capabilities in creating and using technology. The countries in the TAI also divided into four sub-groups called as Leaders (TAI $>0,5)$, Potential Leaders $(T A I=0,35-0,49)$, Dynamic Adopters $(T A I=$ $0,20-0,34$ ), and Marginalized (TAl <0,20) (Desai et al, 2002).

The components of the TAI consist of four main dimensions as total eight indicators. Each dimension has two indicators, and each of four dimensions and eight indicators has equal weight. Four main dimensions are Technology Creation (TC), Diffusion of Recent Innovations (DRI), Diffusion of Old Innovations (DOI), and Human Skills (HS). Two sub-indicators of each dimension in the TAl are summarized below.

- Technology creation represents by the sub-indicators' patents granted per capita and receipts of royalties and license fees from abroad per capita. These sub-indicators reflect respectively the current level of invention activities and the stock of successful past innovations that are still useful and therefore market value (Desai et al, 2002)

- Sub-indicators of diffusion of recent innovations are numbers of Internet hosts per 1000 people and high-andmedium technology exports as a share of all export.

- Diffusion of old innovations measured by telephones mainlines and cellular per 1000 people and electricity consumption per capita (kW per capita) (Desai et al, 2002)

- The two sub-indicators in the human skills are mean years of schooling of the population age 15 and above and gross tertiary science enrolment ratio. These two measures indicate the general level of basic educational skills in the population, in spite of the fact that education quality varies from country to country. (Desai et al, 2002)

In this study, technological capabilities and performances of 105 countries are analyzed and Technology Achievement Index (TAI-16) is calculated using most of the data of 2015. The internet users per 100 people are used instead of the internet hosts per 1000 people which sub-indicator of diffusion of recent innovation as it gives a more certain idea about the diffusion of internet among the population in our study. We also use the high technology exports as a share of all export instead of the high-and-medium technology exports in TAI-02 (Desai et al. 2002). Furthermore, the countries are classified as leaders, potential leaders, dynamic adopters and marginalized countries and created the TAl ranking of the 105 countries.

The rest of this study is organized as follows. Section two provides a brief review of the empirical literature. In the third section presents the data set and methodology, and in the fourth section, the findings and discussions are mentioned. These sections are followed by the conclusion part.

\section{LITERATURE REVIEW}

Technology creation, diffusion, and having human skills have been the key factors for economic growth, development, and global competition. For this reason, there are many studies evaluating the technological performances and progress of the countries using the different methods in the literature. Technology Achievement Index (TAI) developed by Desai et al. (2002) and called TAI-02, is one of these studies.

Desai et al. (2002) calculated the Technology Achievement Index (TAI-02) using data from 72 countries. In their study, they ranked 72 countries according to their TAI values and evaluated the technological performance of the countries based on their capability about creating and using technology but not focus on the overall size of their technological development. Thus, although Finland is a smaller country than USA, UK, and Germany, it has a higher ranking in TAI than those countries (Nasir et al. 2011) As a result, their study shows that there are great differences in technological progress among developing countries (Desai et. al. 2002)

Following TAI-02, TAI-09 was proposed by Nasir et all. (2011). TAl-09 differs from TAl-02 in that it analyzes the technology capacities and capabilities of 91 countries using the data of 2009. Furthermore, the main purpose of TAl-09 indicates the changes take place in the TAI rankings of various countries. Since the data for the two sub-indicators used in 2002 are no longer available, these two sub-indicators revised in TAI-09. The study also compares 56 countries which are included in both TAI-09 and TAI-02 in terms of their technological progress. Later on, The TAl-02 containing 72 countries modified and made compatible with TAI-09. In the result of the study, 20 countries within 56 countries moved up, 23 countries moved 
down and 13 countries retained their ranking positions in the index and $4.7 \%$ reduction is observed in the TAI values from 2002 to 2009.

Archibugi and Coco (2004) presented a new indicator of technological capabilities (ArCo) for measure the developed and developing countries technological capabilities. Index took into account a number of other variables associated with technological change and it allowed for comparison between countries over time. When they developing the index, they benefited from the methodology including Technology Achievement Index, Human Development Report, and Industrial Performance Scoreboard.

Fan et al. (2008) indicated that technology achievement gap among countries could be affected by such effects as that Matthew effect, convergence effect, and balance effects, according to the time sequence. They calculated TAl of 134 developed and developing (regions) countries bu following the method in Technology Achievement Index and extended the index from single year to 21 years between 1985 and 2005. The result of their study indicated that technological gap among countries was getting shorter and to some extent developing countries' technology surpassing strategy was effective. This means that the overall trend was convergence and individual Matthew effect.

Xu et al. (2013) calculated the TAl of 21 innovative cities in the period of 2001-2008. According to their result of their study, TAl of 21 innovative cities and four sub-indicators showed an increasing trend. Furthermore, in terms of diffusion of recent innovations, diffusion of old innovation, and human skills there were no big differences among these cities, apart from the creation of technology which directly results in the differences of TAl among these innovative cities.

Burinskiene (2013) was investigated the relationship between international trade and technological innovations. Burinskiene examined the concept of innovations and presented the models of innovations linked to international trade by using different types of models in the study. Moreover, TAI was presented for 68 countries and the results of TAI were compared with achievements on e-commerce technology in different countries. In this comparison, TAl and the application of e-commerce technologies were conducted to reveal how TAl represents the application of e-commerce technology in countries. Also, the countries classified into groups representing the difference in technological achievement. The empiric study results showed that some countries are ranked higher according to TAl and lower in the application of e-commerce technology or vice versa.

Ali et al. (2014) proposed the TAI-13 OIC to reveal the technological progress of Muslim nations. They ranked 34 Muslim countries, and each sub-dimension of the index included in the ranking. They also made a comparative analysis of TAI ranking of 22 countries, common to the present and previous studies of 2011 under similar conditions, and presented information about the shift in the technological situation of these countries over a period of 5 years. They used the standard deviation approach to investigate the technological spread. Moreover, made a comparison such different indices as $\mathrm{GCl}, \mathrm{HDI}$, and GDP per capita in TAl-13 OIC.

TAl-15 proposed by Shahab is an another study in the Technology Achievement Index (2015). TAl scores of 167 countries calculated in TAI-15. Cluster analysis was used in the TAI-15 and update and enhance the technology achievement index with classification and grouping of the countries by using latest data. By using the cluster analysis countries are classified 31 countries as Leaders, 34 as Potential Leaders, 44 as Dynamic Adopters and 58 as Marginalized. All the features of Potential Leaders such as high levels of human skills and high diffusion of recent innovations in TAI-15 and TAl-02 are the same.

\section{DATA AND METHODOLOGY}

The methodology used to calculate the TAI-16 is based on the original study of Desai et al. TAl which consists of four main dimensions and eight sub-indicators of the dimensions calculate the average of the dimensions of the index based on the selected indicators. Each of four dimensions includes two sub-indicators. Equal weight is given of the indicators in each dimension and in the final index, the dimensions are given one-quarter (equal) weight. The observed minimum and maximum values among all countries with data are selected as goalposts for each of the indicators in these dimensions. The performance on each indicator is stated as a value between 0 and 1 applied the following general formula: (Human Development Report, 2001).

$$
\text { Indicator Index }=\frac{\text { Actual Value }- \text { Observed Minimum Value }}{\text { Observed Maximum Value - Observed Minimum Value }}
$$

The data sources belong to the sub-indicators are stated below. 
The indicators which used to measure technology creation are patents granted per capita and receipts of royalties and license fees from abroad per capita. World Bank World Development Indicators contains the data of receipts of royalties and license fees from abroad per capita. Patents granted per capita data is obtained from the European Patent Office (EPO)

The numbers of Internet hosts per 1000 people and high-and-medium technology exports as a share of all export used to measured the diffusion of recent innovation in the original study of Desai et al. TAI-02. In our study, the internet users per 100 people are used instead of the hosts per 1000 people. We also use the high technology exports as a share of all export instead of the high-and-medium technology exports in TAI-02 (Desai et al. 2002). The data of the internet users per 100 people are acquired from the World Bank World Development Indicators. High technology exports as a share of all exports data are obtained from World Bank World Development Indicators.

For the telephones mainlines and cellular per 1000 people and electricity consumption per capita (kW per capita) subindicators logarithm is taken and capped at OECD average levels in our study. Data regarding Electricity consumption per capita (kW per capita) is taken from World Bank Database. The data of the telephones mainlines and cellular per 1000 people derived from International Telecommunication Union (ITU).

To measuring the human skills dimension used mean years of schooling of the population age 15 and above and gross tertiary science enrolment ratio. The data of mean years of schooling of the population age 15 and above is gathered from the United Nation Devolepment Programme (UNDP) data. The data of gross tertiary science enrolment ratio' data is obtained from International Telecommunication Union (ITU).

\section{FINDINGS AND DISCUSSIONS}

TAl-16 is calculated using Desai's original institutional framework. 105 countries' technological capabilities and performances analyzed using the most of the data of 2015. The internet users per 100 people are used instead of the hosts per 1000 people which sub-indicator of diffusion of recent innovation as it gives a more certain idea about the diffusion of internet among the population in our study. We also use the high technology exports as a share of all export instead of the high-and-medium technology exports in TAl-02 (Desai et al. 2002). Moreover, two sub-indicators in the diffusion of old innovations telephones mainlines and cellular per 1000 people and electricity consumption (kW per capita) logarithm was taken and capped at OECD average levels.

Table 1 in appendix gives the TAl-16 ranking of 105 countries. The values indicate great differences between developed and developing countries within specific categories. While the highest TAl value is 0.813 for Switzerland, the lowest value is $0,028$ for Ethiopia. Furthermore, TAl-16 values of the 105 countries are classified as Leaders (TAI $>0,5)$, Potential Leaders $(\mathrm{TAl}=0,35-0,49)$, Dynamic Adopters $(\mathrm{TAl}=0,20-0,34)$, and Marginalized $(\mathrm{TAl}<0,20)$ following the methodology in TAI-02. According to this classification, 40 countries as Leaders, 38 countries as Potential Leaders, 17 countries as Dynamic Adopters, and 10 countries as Marginalized identified.

- Leader (TAI > 0,5): Technology creation and innovation capacity are important for all the countries and provide highest technological progress. Leaders as owners of the technological innovation get a big advantage in the global economy. This group is at the top of the technological innovation and mostly consist of the developed countries. They also have a high achievement in technology creation, diffusion, and skills. Such developed countries as Switzerland, Luxembourg, Netherlands, Sweden, Korea Rep., and the United States are including in the top ten among Leaders.

- Potential Leaders $(\mathrm{TAI}=0,35-0,49)$ : Most of the countries in Potential Leaders are developing countries. Potential Leaders comprise 38 countries include the countries as Turkey, Brazil, Chile, Chine, Colombia, Portugal, Thailand. Most of the countries in this group have used old technologies extensively and invested in high-level human skills. However, innovation level of these countries is low.

- $\quad$ Dynamic Adopters (TAI = 0,20-0,34): Seventeen countries such as Indonesia, Egypt, Cuba, Sri Lanka come under the Dynamic Adapters category. Some countries in this group have human skills levels and diffusion recent and old technologies comparable with Potential Leaders.

- Marginalized (TAI < 0,20): Marginalized countries consist of eleven countries include Pakistan, Senegal, Sudan, Ethiopia. These countries are lagging behind in almost every aspect of technological success. The countries in this group have low levels of technological advance and need to have a long way to go technology diffusion and human skill building. In large parts of these countries, people still do not have access to "old" technologies.

\section{CONCLUSION}

In this study, technological capabilities and performances of 105 countries were analyzed and Technology Achievement Index (TAl-16) was calculated using most of the data of 2015. TAl-16 was calculated based on Desai's original study. Moreover, TAl-16 values of the 105 countries were classified as Leaders (TAl > 0,5), Potential Leaders (TAl = 0,35-0,49), Dynamic Adopters (TAI =0,20-0,34), and Marginalized $(\mathrm{TAl}<0,20)$ following the methodology in TAl-02. According to TAl-16 classification, the countries were identified as follows; 40 countries as Leaders, 38 countries as Potential Leaders, 17 
countries as Dynamic Adopters, and 10 countries as Marginalized. Furthermore, TAl ranking of the 105 countries was created. In this classification, while Switzerland had the highest with 0.813 TAl value, Ethiopia had the lowest value with 0,028 TAI value.

Following the TAI-02, TAI-09 and TAI-15 were proposed. All these studies investigated the countries technological performance. While TAI-02 analyzed 72 countries, TAI-09 investigated 91 countries and the TAI-15 analyzed 167 countries. The changes and developments in the technological performances of the countries within the years can be seen and compared in these studies. Looking at the rankings of Turkey in these indices, it has been observed that ranked 79th among Dynamic Leaders in 167 countries in TAI-15.

In our study, Turkey with 0,412 TAl value was included in Potential Leaders category and ranked in 66 among 105 countries. In this frame, when the countries are ranked according to four main dimensions of the index, Turkey was in the 38th place in Technology Creation index; 73rd place in Diffusion of Recent Innovation Index, 70th place in Diffusion of Old Innovation index and 21st place in the Human Skills index. The fact that the diffusion of recent innovation and diffusion of old innovation index values were low was one of the factors pushing down the ranking of technology achievement index of Turkey. Because the calculation of the diffusion of old innovations index by the logarithm function and the second derivative of the logarithm function is negative, the increasing in this sub-indicator that contributes to the TAl has a decreasingly growing course. Therefore, if Turkey attaches more importance to other sub-indices in order to increase TAI values, it is expected that TAl value will be reflected positively.

\section{REFERENCES}

Ali, T.M., Kiani, A.K., Asrar, M., Bashir T., 2014, "Technology Achievement Index of Muslim Nations-Ranking and Comparative Study" Science, Technology and Development, Vol: 33, (2), pp. 49-62

Archibugi, D., Coco, A., 2004, “A New Indicator of Technological Capabilities for Developed and Developing Countries (ArCo), World Development Vol. 32, No: 4, pp. 629-654

Burinskiene, A., 2013, "International Trade, Innovations and Technolojical Achievement in Countries", DAAAM International Scientific Book, pp.795-812

Desai, M., Fukuda-Parr, S., Johansson C., Sagasti F., 2002, "Measuring the Technology Achievement of Nations and the Capacity to Participate in the Network Age", Journal of Human Develeopment, Vol: 3, No: 1, pp. 96-122

Fan, L., Zheng J., Jiang L., 2008, “Technological Gap, Technology Diffusion and Convergence - Evidence from 134 Countries' Technology Achievement Index", China Industrial Economics, No:9, pp. 69-76

Nasir, A., Ali, T.M., Shahdin S., Rahman T.U., 2011, "Technology Achievement Index 2009: Ranking and Comparative Study of Nations", Scientometrics, 87, pp. 41-62

Shahab, M., 2015, "Technology Achievement Index 2015: Mapping the Global Patterns of Technological Capacity in the Network Age", Elsevier Editorial System for Technology Forecasting \& Social Change, pp. 2-35

United Nations Development Programme (UNDP), 2001, Human Develeopment Report 2001

United Nations Development Programme (UNDP), 2001, Human Develeopment Report 2014

Xu, Z., Deng Q., 2013, “The Differences and Convergence Effect among National Innovative Cities' Innovation Abilities: Based on Technology Achievement Index" Science and Management of S.\&T., No:01 


\section{Appendix}

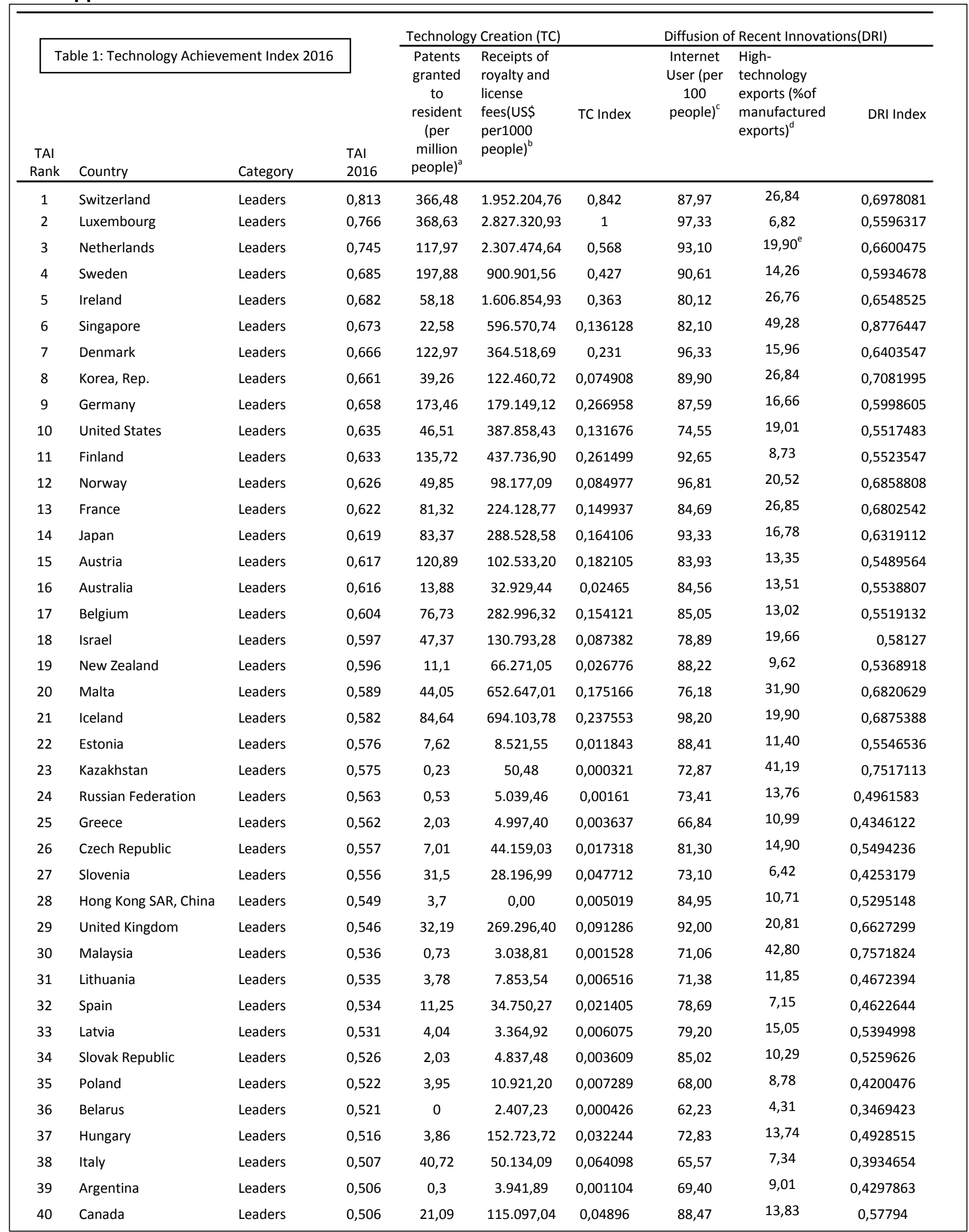




\begin{tabular}{|c|c|c|c|c|c|c|c|c|c|}
\hline 41 & Croatia & Potential leaders & 0,499 & 1,42 & $10.805,47$ & 0,003837 & 69,80 & 8,98 & 0,4316911 \\
\hline 42 & Chile & Potential leaders & 0,499 & 0,89 & $4.879,51$ & 0,00207 & 64,29 & 5,90 & 0,3729536 \\
\hline 43 & Ukraine & Potential leaders & 0,496 & 0,04 & $1.880,61$ & 0,000387 & 49,26 & 7,27 & 0,3049207 \\
\hline 44 & Bulgaria & Potential leaders & 0,492 & 0,98 & $6.950,41$ & 0,002558 & 56,66 & 7,65 & 0,348336 \\
\hline 45 & Bahrain & Potential leaders & 0,491 & 0 & 0 & 0 & 93,48 & 0,96 & 0,4836099 \\
\hline 46 & Cyprus & Potential leaders & 0,482 & 12,01 & 0 & 0,01629 & 71,72 & 6,15 & 0,4153491 \\
\hline 47 & Saudi Arabia & Potential leaders & 0,478 & 1,55 & 0 & 0,002102 & 69,62 & 0,77 & 0,3533541 \\
\hline 48 & Qatar & Potential leaders & 0,47 & 0,89 & 0 & 0,001207 & 92,88 & 3,41 & 0,5034845 \\
\hline 49 & Serbia & Potential leaders & 0,468 & 0 & 0 & 0,001128 & 65,32 & 0 & 0,3229051 \\
\hline 50 & Portugal & Potential leaders & 0,467 & 4,45 & $8.573,89$ & 0,007552 & 68,63 & 4,59 & 0,3839719 \\
\hline 51 & Brunei Darussalam & Potential leaders & 0,458 & 0 & 0 & 0 & 71,20 & 17,93 & 0,5235925 \\
\hline 52 & Costa Rica & Potential leaders & 0,451 & 0 & 0 & 0 & 59,76 & 16,83 & 0,4515897 \\
\hline 53 & Philippines & Potential leaders & 0,443 & 0,04 & 111,14 & 0 & 40,70 & 53,06 & 0,6903662 \\
\hline 54 & Kuwait & Potential leaders & 0,442 & 0,77 & 0 & 0,001044 & 82,08 & 2,72 & 0,4387832 \\
\hline 55 & Oman & Potential leaders & 0,439 & 0 & 0,00 & 0 & 74,17 & 4,13 & 0,4094845 \\
\hline 56 & Georgia & Potential leaders & 0,437 & 0 & 154,06 & 0 & 45,16 & 5,57 & 0,2667987 \\
\hline 57 & Romania & Potential leaders & 0,436 & 0,45 & $4.494,71$ & 0,001405 & 55,76 & 7,50 & 0,3421426 \\
\hline 58 & Brazil & Potential leaders & 0,426 & 0,35 & $2.795,71$ & 0,000969 & 59,08 & 12,31 & 0,4052662 \\
\hline 59 & Azerbaijan & Potential leaders & 0,424 & 0 & 0 & 0 & 77,00 & 2,53 & 0,4097025 \\
\hline 60 & Armenia & Potential leaders & 0,423 & 0 & 0 & 0 & 58,25 & 5,27 & 0,3345424 \\
\hline 61 & Thailand & Potential leaders & 0,422 & 0,07 & $1.245,89$ & 0,000315 & 39,32 & 21,44 & 0,3849261 \\
\hline 62 & China & Potential leaders & 0,419 & 1,03 & 790,97 & 0,001537 & 50,30 & 25,75 & 0,4847135 \\
\hline 63 & Jordan & Potential leaders & 0,416 & 0 & $1.680,23$ & 0,000297 & 53,40 & 1,82 & 0,2758538 \\
\hline 64 & Macedonia, FYR & Potential leaders & 0,414 & 0 & $4.449,03$ & 0,000787 & 70,38 & 2,99 & 0,3783237 \\
\hline 65 & South Africa & Potential leaders & 0,413 & 1,07 & $1.876,35$ & 0,001783 & 51,92 & 5,88 & 0,3061673 \\
\hline 66 & Turkey & Potential leaders & 0,412 & 2,77 & 0 & 0,003757 & 53,74 & 2,16 & 0,2809341 \\
\hline 67 & Albania & Potential leaders & 0,41 & 0 & 662,81 & 0,000117 & 63,25 & 1,49 & 0,3258044 \\
\hline 68 & Moldova & Potential leaders & 0,407 & 0 & $1.260,50$ & 0,000223 & 49,84 & 3,99 & 0,2771243 \\
\hline 69 & Kyrgyz Republic & Potential leaders & 0,404 & 0 & 234,02 & 0 & 30,25 & 11,86 & 0,2458114 \\
\hline 70 & Vietnam & Potential leaders & 0,402 & 0,04 & 0 & 0 & 52,72 & $26,93 e$ & 0,5088412 \\
\hline 71 & Uruguay & Potential leaders & 0,401 & 0,58 & 47,79 & 0,000795 & 64,60 & 13,85 & 0,4495217 \\
\hline 72 & Panama & Potential leaders & 0,394 & 0,51 & $1.494,98$ & 0,000956 & 51,21 & 0 & 0,24691 \\
\hline 73 & Lebanon & Potential leaders & 0,392 & 0 & $4.083,90$ & 0,000722 & 74,00 & $2,07 e$ & 0,389165 \\
\hline 74 & Colombia & Potential leaders & 0,386 & 0,08 & $1.086,29$ & 0,000301 & 55,90 & 9,49 & 0,3616408 \\
\hline 75 & Mauritius & Potential leaders & 0,385 & 6,34 & $1.043,55$ & 0,008784 & 50,14 & 0,06 & 0,2417258 \\
\hline 76 & Mexico & Potential leaders & 0,377 & 0,33 & $2.423,07$ & 0,000876 & 57,43 & 14,69 & 0,4188336 \\
\hline 77 & Mongolia & Potential leaders & 0,365 & 0 & 806,67 & 0,000143 & 21,44 & 4,03 & 0,1245657 \\
\hline 78 & Tunisia & Potential leaders & 0,35 & 0,27 & $1.959,67$ & 0,000713 & 48,52 & 6,33 & 0,2920672 \\
\hline 79 & $\begin{array}{l}\text { Bosnia and } \\
\text { Herzegovina }\end{array}$ & Dynamic Adopters & 0,342 & 0,26 & $3.383,61$ & 0,000951 & 65,07 & 2,82 & 0,3481141 \\
\hline 80 & Botswana & Dynamic Adopters & 0,34 & 0 & 53,90 & 0 & 27,50 & 0,63 & 0,1251941 \\
\hline
\end{tabular}




\begin{tabular}{|c|c|c|c|c|c|c|c|c|c|}
\hline 81 & Dominican Republic & Dynamic Adopters & 0,339 & 0 & 0 & 0 & 51,93 & 3,83 & 0,286907 \\
\hline 82 & Jamaica & Dynamic Adopters & 0,334 & 0 & $2.025,55$ & 0,000358 & 43,18 & 0,09 & 0,2044683 \\
\hline 83 & Indonesia & Dynamic Adopters & 0,308 & 0 & 211,46 & 0 & 21,98 & $6,97^{e}$ & 0,155168 \\
\hline 84 & Egypt, Arab Rep. & Dynamic Adopters & 0,308 & 0,02 & 0 & 0 & 35,90 & 0,78 & 0,1718573 \\
\hline 85 & Sri Lanka & Dynamic Adopters & 0,308 & 0 & 0 & 0 & 29,99 & 0,84 & 0,1405213 \\
\hline 86 & El Salvador & Dynamic Adopters & 0,307 & 0 & $4.756,89$ & 0,000841 & 26,92 & 4,39 & 0,1574091 \\
\hline 87 & Peru & Dynamic Adopters & 0,306 & 0,06 & 694,97 & 0,000204 & 40,90 & 4,74 & 0,2360495 \\
\hline 88 & Morocco & Dynamic Adopters & 0,304 & 0 & 96,21 & 0 & 57,08 & 3,54 & 0,3118722 \\
\hline 89 & Bolivia & Dynamic Adopters & 0,275 & 0 & $2.091,54$ & 0,00037 & 45,10 & 6,46 & 0,2748943 \\
\hline 90 & Cuba & Dynamic Adopters & 0,256 & 0,7 & 0 & 0,000949 & 31,11 & 0 & 0,1386685 \\
\hline 91 & Guatemala & Dynamic Adopters & 0,25 & 0 & $1.008,23$ & 0,000178 & 27,10 & 5,02 & 0,1643815 \\
\hline 92 & Nepal & Dynamic Adopters & 0,248 & 0 & 0 & 0 & 17,58 & 0,62 & 0,0716875 \\
\hline 93 & India & Dynamic Adopters & 0,229 & 0,14 & 355,86 & 0,000253 & 26,00 & 7,52 & 0,182001 \\
\hline 94 & Honduras & Dynamic Adopters & 0,226 & 0 & 107,75 & 0 & 20,36 & $2,42^{\mathrm{e}}$ & 0,1035528 \\
\hline 95 & Zimbabwe & Dynamic Adopters & 0,207 & 0 & 145,35 & 0 & 16,36 & 2,89 & 0,0865094 \\
\hline 96 & Cote d'Ivoire & Marginalized Countries & 0,195 & 0 & 0 & 0 & 21,00 & 4,79 & 0,1293436 \\
\hline 97 & Cameroon & Marginalized Countries & 0,181 & 0 & 0 & 0 & 20,68 & 3,71 & 0,1174618 \\
\hline 98 & Bangladesh & Marginalized Countries & 0,157 & 0 & 7,42 & 0 & 14,40 & 0 & 0,0486859 \\
\hline 99 & Senegal & Marginalized Countries & 0,154 & 0 & 0,00 & 0 & 21,69 & 3,62 & 0,1220409 \\
\hline 100 & Pakistan & Marginalized Countries & 0,151 & 0 & 79,40 & 0 & 18,00 & 1,56 & 0,0827494 \\
\hline 101 & Mozambique & Marginalized Countries & 0,147 & 0 & 0 & 0 & 9,00 & 11,61 & 0,1290274 \\
\hline 102 & Sudan & Marginalized Countries & 0,124 & 0 & 0,01 & 0 & 26,61 & 0 & 0,1144707 \\
\hline 103 & Togo & Marginalized Countries & 0,104 & 0 & 0 & 0 & 7,12 & 0,41 & 0,0133526 \\
\hline 104 & Tanzania & Marginalized Countries & 0,098 & 0 & 3,70 & 0 & 5,36 & 0,76 & 0,0071346 \\
\hline 105 & Ethiopia & Marginalized Countries & 0,028 & 0 & 0 & 0 & 11,60 & 4,00 & 0,0713306 \\
\hline
\end{tabular}




\begin{tabular}{|c|c|c|c|c|c|c|c|c|c|}
\hline \multirow[b]{3}{*}{ TAI Rank } & \multirow{3}{*}{ e 1: Technology Achieve } & \multirow[b]{3}{*}{ Category } & \multirow[b]{3}{*}{ TAI 2016} & \multicolumn{3}{|c|}{ Diffusion of Old İnnovations(DOI) } & \multicolumn{3}{|c|}{ Development of Human Skills } \\
\hline & & & & \multirow{2}{*}{$\begin{array}{l}\text { Telephone } \\
\text { (mainlines } \\
+ \text { cellular } \\
\text { per } 1000 \\
\text { people) }^{f}\end{array}$} & \multirow{2}{*}{$\begin{array}{l}\text { Electricity } \\
\text { consumption } \\
\text { (kwh per } \\
\text { capita })^{\mathrm{g}}\end{array}$} & \multirow{2}{*}{ DOI Index } & \multirow{2}{*}{$\begin{array}{c}\text { Mean } \\
\text { years of } \\
\text { schooling }\end{array}$} & \multirow{2}{*}{$\begin{array}{c}\text { Gross } \\
\text { enrolment } \\
\text { ratio, tertiary } \\
\text { (\%of tertiary } \\
\text { school-age } \\
\text { population) }\end{array}$} & \multirow{2}{*}{ DHS Index } \\
\hline & & & & & & & & & \\
\hline 1 & Switzerland & Leaders & 0,813 & 1867,2 & $7.807,31$ & 0,983406 & 12,8 & $57.229^{j}$ & 0,73 \\
\hline 2 & Luxembourg & Leaders & 0,766 & 1994,8 & $14.193,17$ & 1 & 11,7 & $19.407^{\prime}$ & 0,51 \\
\hline 3 & Netherlands & Leaders & 0,745 & 1648,1 & $6.821,06$ & 0,969789 & 11,9 & $78.501^{1}$ & 0,78 \\
\hline 4 & Sweden & Leaders & 0,685 & 1670,5 & $13.870,39$ & 1 & 12,1 & $62.353^{\mathrm{j}}$ & 0,72 \\
\hline 5 & Ireland & Leaders & 0,682 & 1445,8 & $5.701,90$ & 0,918054 & 12,2 & $77.626^{\mathrm{j}}$ & 0,79 \\
\hline 6 & Singapore & Leaders & 0,673 & 1824,1 & $8.839,71$ & 0,995928 & 10,6 & $69,811^{1}$ & 0,68 \\
\hline 7 & Denmark & Leaders & 0,666 & 1582,6 & $6.039,61$ & 0,957419 & 12,7 & $81.516^{\mathrm{j}}$ & 0,83 \\
\hline 8 & Korea, Rep. & Leaders & 0,661 & 1765,2 & $10.427,89$ & 1 & 11,9 & 95.345 & 0,86 \\
\hline 9 & Germany & Leaders & 0,658 & 1716,4 & $7.019,01$ & 0,972674 & 13,1 & 68.265 & 0,79 \\
\hline 10 & United States & Leaders & 0,635 & 1559,9 & $12.988,26$ & 0,994535 & 12,9 & 85.796 & 0,86 \\
\hline 11 & Finland & Leaders & 0,633 & 1452,9 & $15.509,73$ & 0,968154 & 10,3 & 87.289 & 0,75 \\
\hline 12 & Norway & Leaders & 0,626 & 1294,9 & $23.325,75$ & 0,925412 & 12,6 & 76.696 & 0,81 \\
\hline 13 & France & Leaders & 0,622 & 1625,2 & $7.373,98$ & 0,977648 & 11,1 & $64.390^{j}$ & 0,68 \\
\hline 14 & Japan & Leaders & 0,619 & 1767,7 & $7.835,60$ & 0,983771 & 11,5 & $63.362^{\mathrm{j}}$ & 0,7 \\
\hline 15 & Austria & Leaders & 0,617 & 1995,9 & $8.513,01$ & 0,992131 & 10,8 & 81.540 & 0,75 \\
\hline 16 & Australia & Leaders & 0,616 & 1707,5 & $10.133,86$ & 1 & 13 & 90.306 & 0,89 \\
\hline 17 & Belgium & Leaders & 0,604 & 1558,3 & $7.966,69$ & 0,979597 & 11,3 & $73.318^{j}$ & 0,73 \\
\hline 18 & Israel & Leaders & 0,597 & 1765,5 & $6.558,72$ & 0,965835 & 12,5 & $66.181^{j}$ & 0,76 \\
\hline 19 & New Zealand & Leaders & 0,596 & 1620,8 & $9.084,22$ & 0,998679 & 12,5 & $80.882^{j}$ & 0,82 \\
\hline 20 & Malta & Leaders & 0,589 & 1826,9 & $4.735,77$ & 0,932999 & 10,3 & 46.973 & 0,57 \\
\hline 21 & Iceland & Leaders & 0,582 & 1639,5 & $54.799,17$ & 1 & 10,6 & $81,26^{\prime}$ & 0,4 \\
\hline 22 & Estonia & Leaders & 0,576 & 1789,7 & $6.664,66$ & 0,96745 & 12,5 & 69.550 & 0,77 \\
\hline 23 & Kazakhstan & Leaders & 0,575 & 1816,1 & $4.892,50$ & 0,936282 & 11,4 & 46.039 & 0,61 \\
\hline 24 & Russian Federation & Leaders & 0,563 & 1849,7 & $6.539,21$ & 0,965534 & 12 & $78.653 \mathrm{j}$ & 0,79 \\
\hline 25 & Greece & Leaders & 0,562 & 1602,3 & $5.029,00$ & 0,939057 & 10,3 & $113.871 \mathrm{j}$ & 0,87 \\
\hline 26 & Czech Republic & Leaders & 0,557 & 1407,2 & $6.284,79$ & 0,917822 & 12,3 & $66.017 \mathrm{j}$ & 0,75 \\
\hline 27 & Slovenia & Leaders & 0,556 & 1494,4 & $6.833,17$ & 0,948577 & 11,9 & 82.926j & 0,8 \\
\hline 28 & Hong Kong SAR, China & Leaders & 0,549 & 2879,1 & $5.933,63$ & 0,955736 & 11,2 & 68.475 & 0,71 \\
\hline 29 & United Kingdom & Leaders & 0,546 & 1761,5 & $5.407,29$ & 0,94637 & 13,1 & $61 n$ & 0,48 \\
\hline 30 & Malaysia & Leaders & 0,536 & 1585,4 & $4.511,97$ & 0,928118 & 10 & 26.074 & 0,46 \\
\hline 31 & Lithuania & Leaders & 0,535 & 1582,6 & $3.663,67$ & 0,907017 & 12,4 & $68.531 \mathrm{j}$ & 0,76 \\
\hline 32 & Spain & Leaders & 0,534 & 1497,2 & $5.401,05$ & 0,925557 & 9,6 & 89.670 & 0,73 \\
\hline 33 & Latvia & Leaders & 0,531 & 1450,3 & $3.472,54$ & 0,869205 & 11,5 & 67.039j & 0,71 \\
\hline 34 & Slovak Republic & Leaders & 0,526 & 1381,9 & $5.202,47$ & 0,89203 & 12,2 & $52.923 j$ & 0,68 \\
\hline 35 & Poland & Leaders & 0,522 & 1663,8 & $3.937,65$ & 0,91439 & 11,8 & 71.1581 & 0,75 \\
\hline
\end{tabular}




\begin{tabular}{|c|c|c|c|c|c|c|c|c|c|}
\hline 36 & Belarus & Leaders & 0,521 & 1726,8 & $3.648,32$ & 0,906695 & 12 & 87.940 & 0,83 \\
\hline 37 & Hungary & Leaders & 0,516 & 1501,3 & $3.890,29$ & 0,89349 & 11,6 & 50.862 & 0,64 \\
\hline 38 & Italy & Leaders & 0,507 & 1751,7 & $5.159,18$ & 0,941634 & 10,1 & $63.095^{j}$ & 0,63 \\
\hline 39 & Argentina & Leaders & 0,506 & 1706 & $3.093,35$ & 0,890057 & 9,8 & $82.917^{j}$ & 0,71 \\
\hline 40 & Canada & Leaders & 0,506 & 1265 & $15.519,34$ & 0,91674 & 13 & $60^{m}$ & 0,48 \\
\hline 41 & Croatia & Potential leaders & 0,499 & 1384,7 & $3.754,27$ & 0,859886 & 11 & $69.544^{j}$ & 0,7 \\
\hline 42 & Chile & Potential leaders & 0,499 & 1486,9 & $3.878,91$ & 0,889616 & 9,8 & 88.577 & 0,73 \\
\hline 43 & Ukraine & Potential leaders & 0,496 & 1656,4 & $3.600,23$ & 0,905357 & 11,3 & $82.305^{j}$ & 0,77 \\
\hline 44 & Bulgaria & Potential leaders & 0,492 & 1525,4 & $4.639,71$ & 0,917165 & 10,6 & 73.934 & 0,7 \\
\hline 45 & Bahrain & Potential leaders & 0,491 & 2058,6 & $18.216,62$ & 1 & 9,4 & 37.375 & 0,48 \\
\hline 46 & Cyprus & Potential leaders & 0,482 & 1231,9 & $3.594,79$ & 0,812101 & 11,6 & 60.101 & 0,69 \\
\hline 47 & Saudi Arabia & Potential leaders & 0,478 & 1891,2 & $8.741,42$ & 0,994801 & 8,7 & 63.066 & 0,56 \\
\hline 48 & Qatar & Potential leaders & 0,47 & 1767,2 & $15.470,99$ & 1 & 9,1 & 17.219 & 0,37 \\
\hline 49 & Serbia & Potential leaders & 0,468 & 1569,9 & $4.444,22$ & 0,9235 & 10,5 & 58.287 & 0,63 \\
\hline 50 & Portugal & Potential leaders & 0,467 & 1545,5 & $4.685,05$ & 0,923005 & 8,2 & $65.607^{j}$ & 0,55 \\
\hline 51 & Brunei Darussalam & Potential leaders & 0,458 & 1170,9 & $9.703,55$ & 0,888042 & 8,8 & 30.844 & 0,42 \\
\hline 52 & Costa Rica & Potential leaders & 0,451 & 1678,4 & $1.954,56$ & 0,843767 & 8,4 & 53.629 & 0,51 \\
\hline 53 & Philippines & Potential leaders & 0,443 & 1189,2 & 692,06 & 0,63288 & 8,9 & $35.753 j$ & 0,45 \\
\hline 54 & Kuwait & Potential leaders & 0,442 & 2451,6 & $14.910,58$ & 1 & 7,2 & 27.0271 & 0,33 \\
\hline 55 & Oman & Potential leaders & 0,439 & 1703,2 & $5.981,45$ & 0,956545 & 8 & 31.922 & 0,39 \\
\hline 56 & Georgia & Potential leaders & 0,437 & 1510,2 & $2.459,75$ & 0,849461 & 12,1 & 43.419 & 0,63 \\
\hline 57 & Romania & Potential leaders & 0,436 & 1269,3 & $2.494,53$ & 0,786363 & 10,8 & 53.220 & 0,62 \\
\hline 58 & Brazil & Potential leaders & 0,426 & 1480,4 & $2.529,30$ & 0,844874 & 7,7 & 49.279j & 0,45 \\
\hline 59 & Azerbaijan & Potential leaders & 0,424 & 1299,6 & $2.092,54$ & 0,777403 & 11,2 & 25.483 & 0,51 \\
\hline 60 & Armenia & Potential leaders & 0,423 & 1343,3 & $1.870,20$ & 0,778355 & 10,9 & 44.309 & 0,58 \\
\hline 61 & Thailand & Potential leaders & 0,422 & 1606,1 & $2.470,77$ & 0,867398 & 7,3 & 48.857 & 0,43 \\
\hline 62 & China & Potential leaders & 0,419 & 1086,6 & $3.762,08$ & 0,770094 & 7,5 & 43.392 & 0,42 \\
\hline 63 & Jordan & Potential leaders & 0,416 & 1842,3 & $2.103,86$ & 0,85119 & 9,9 & 44.869 & 0,54 \\
\hline 64 & Macedonia, FYR & Potential leaders & 0,414 & 1163,7 & $3.556,50$ & 0,789877 & 9,3 & $39.594 j$ & 0,49 \\
\hline 65 & South Africa & Potential leaders & 0,413 & 1722,3 & $4.325,52$ & 0,923863 & 9,9 & $19.375 j$ & 0,42 \\
\hline 66 & Turkey & Potential leaders & 0,412 & 1110,1 & $2.744,84$ & 0,746251 & 7,6 & $86.309 j$ & 0,62 \\
\hline 67 & Albania & Potential leaders & 0,41 & 1134,7 & $2.531,89$ & 0,746246 & 9,3 & 58.109 & 0,57 \\
\hline 68 & Moldova & Potential leaders & 0,407 & 1430,3 & $1.352,79$ & 0,768996 & 11,2 & 41.213 & 0,58 \\
\hline 69 & Kyrgyz Republic & Potential leaders & 0,404 & 1399,5 & $1.887,02$ & 0,794473 & 10,6 & $45.917 \mathrm{j}$ & 0,57 \\
\hline 70 & Vietnam & Potential leaders & 0,402 & 1369,6 & $1.305,58$ & 0,749315 & 7,5 & 28.835 & 0,35 \\
\hline 71 & Uruguay & Potential leaders & 0,401 & 1924,7 & $2.985,06$ & 0,886464 & 8,5 & 0 & 0,27 \\
\hline 72 & Panama & Potential leaders & 0,394 & 1897,5 & $2.038,00$ & 0,847983 & 9,3 & 38.739 & 0,48 \\
\hline 73 & Lebanon & Potential leaders & 0,392 & 1122 & $3.194,07$ & 0,765493 & 7,9 & 38.484 & 0,42 \\
\hline 74 & Colombia & Potential leaders & 0,386 & 1300,9 & $1.177,11$ & 0,719765 & 7,3 & 55.589 & 0,46 \\
\hline 75 & Mauritius & Potential leaders & 0,385 & 1708,9 & $2.148,33$ & 0,853298 & 8,5 & 36.667 & 0,43 \\
\hline 76 & Mexico & Potential leaders & 0,377 & 1018,7 & $2.056,96$ & 0,685264 & 8,5 & $29.940 \mathrm{j}$ & 0,4 \\
\hline 77 & Mongolia & Potential leaders & 0,365 & 1137,1 & $1.908,94$ & 0,718554 & 9,3 & 68.567 & 0,62 \\
\hline 78 & Tunisia & Potential leaders & 0,35 & 1383,1 & $1.434,62$ & 0,76246 & 6,8 & 34.606 & 0,35 \\
\hline
\end{tabular}




\begin{tabular}{|c|c|c|c|c|c|c|c|c|c|}
\hline 79 & $\begin{array}{l}\text { Bosnia and } \\
\text { Herzegovina }\end{array}$ & Dynamic Adopters & 0,342 & 1103,8 & $3.219,01$ & 0,760206 & 8,3 & $38^{n}$ & 0,26 \\
\hline 80 & Botswana & Dynamic Adopters & 0,34 & 1768 & $1.563,51$ & 0,821259 & 8,9 & $27.513^{j}$ & 0,41 \\
\hline 81 & Dominican Republic & Dynamic Adopters & 0,339 & 948,4 & $1.516,52$ & 0,627983 & 7,6 & $47.515 j$ & 0,44 \\
\hline 82 & Jamaica & Dynamic Adopters & 0,334 & 1205 & $1.126,47$ & 0,686903 & 9,7 & 27.220 & 0,45 \\
\hline 83 & Indonesia & Dynamiz Adopters & 0,308 & 1411 & 787,68 & 0,709421 & 7,6 & $31.102 \mathrm{j}$ & 0,37 \\
\hline 84 & Egypt, Arab Rep. & Dynamic Adopters & 0,308 & 1183,5 & $1.697,47$ & 0,721564 & 6,5 & 36.228 & 0,34 \\
\hline 85 & Sri Lanka & Dynamic Adopters & 0,308 & 1258 & 525,88 & 0,626073 & 10,8 & 19.796 & 0,47 \\
\hline 86 & El Salvador & Dynamic Adopters & 0,307 & 1599,5 & 915,00 & 0,767238 & 6,5 & $28.852 \mathrm{j}$ & 0,31 \\
\hline 87 & Peru & Dynamic Adopters & 0,306 & 1192,1 & $1.269,77$ & 0,69498 & 9 & 0 & 0,29 \\
\hline 88 & Morocco & Dynamic Adopters & 0,304 & 1334,2 & 866,24 & 0,698229 & 4,4 & 28.143 & 0,2 \\
\hline 89 & Bolivia & Dynamic Adopters & 0,275 & 1001,7 & 705,29 & 0,571091 & 8,2 & 0 & 0,25 \\
\hline 90 & Cuba & Dynamic Adopters & 0,256 & 411,7 & $1.425,48$ & 0,31194 & 11,5 & 36.280 & 0,57 \\
\hline 91 & Guatemala & Dynamic Adopters & 0,25 & 1220,5 & 555,04 & 0,62028 & 5,6 & 18.3251 & 0,22 \\
\hline 92 & Nepal & Dynamic Adopters & 0,248 & 997,3 & 128,15 & 0,828465 & 3,3 & 14.940 & 0,09 \\
\hline 93 & India & Dynamic Adopters & 0,229 & 800,5 & 765,00 & 0,496045 & 5,4 & $25.535 j$ & 0,24 \\
\hline 94 & Honduras & Dynamic Adopters & 0,226 & 1014,4 & 720,98 & 0,577986 & 5,5 & $21.184 j$ & 0,22 \\
\hline 95 & Zimbabwe & $\begin{array}{l}\text { Dynamic Adopters } \\
\text { Marginalized }\end{array}$ & 0,207 & 870,1 & 531,75 & 0,490323 & 7,3 & 8.433 & 0,25 \\
\hline 96 & Cote d'Ivoire & $\begin{array}{l}\text { Countries } \\
\text { Marginalized }\end{array}$ & 0,195 & 1206,1 & 252,38 & 0,536408 & 4,3 & 9.155 & 0,11 \\
\hline 97 & Cameroon & $\begin{array}{l}\text { Countries } \\
\text { Marginalized }\end{array}$ & 0,181 & 763,6 & 278,06 & 0,37648 & 6 & 17.478 & 0,23 \\
\hline 98 & Bangladesh & $\begin{array}{l}\text { Countries } \\
\text { Marginalized }\end{array}$ & 0,157 & 824,4 & 293,02 & 0,410208 & 5,1 & 13.440j & 0,17 \\
\hline 99 & Senegal & $\begin{array}{l}\text { Countries } \\
\text { Marginalized }\end{array}$ & 0,154 & 1019,6 & 219,25 & 0,459859 & 2,5 & 10.386 & 0,04 \\
\hline 100 & Pakistan & $\begin{array}{l}\text { Countries } \\
\text { Marginalized }\end{array}$ & 0,151 & 688 & 449,97 & 0,386309 & 4,7 & 9.927 & 0,14 \\
\hline 101 & Mozambique & $\begin{array}{l}\text { Countries } \\
\text { Marginalized }\end{array}$ & 0,147 & 745,7 & 435,60 & 0,412935 & 3,2 & $5.974 j$ & 0,05 \\
\hline 102 & Sudan & $\begin{array}{l}\text { Countries } \\
\text { Marginalized }\end{array}$ & 0,124 & 708,3 & 158,66 & 0,291998 & 3,1 & $16.320 \mathrm{j}$ & 0,09 \\
\hline 103 & Togo & $\begin{array}{l}\text { Countries } \\
\text { Marginalized }\end{array}$ & 0,104 & 684,4 & 147,50 & 0,271903 & 4,5 & 10.625 & 0,13 \\
\hline 104 & Tanzania & $\begin{array}{l}\text { Countries } \\
\text { Marginalized }\end{array}$ & 0,098 & 761,3 & 89,48 & 0,261036 & 5,1 & 3.647 & 0,13 \\
\hline 105 & Ethiopia & Countries & 0,028 & 436,6 & 64,62 & 0,021795 & 2,4 & $8.126 j$ & 0,02 \\
\hline $\begin{array}{l}\text { Notes: } \\
\text { a Related } \\
\text { b Data o } \\
\text { Therefor } \\
\text { Bank Dat } \\
\text { c Related } \\
\text { d In TAI-C } \\
\text { internet } \\
\text { e For pur } \\
\text { Relatec } \\
\text { f Related } \\
\text { OECD co } \\
\text { g For pur } \\
\text { (9204) w } \\
\text { h Related } \\
\text { j Related } \\
\text { k Related } \\
\text { I Related } \\
\text { m The ne }\end{array}$ & $\begin{array}{l}\text { the year of } 2015 \text { data } \\
\text { patents and royalties } \\
\text { value '0' for the miss } \\
\text { ase } \\
\text { the year of } 2015 \text { data } \\
\text { (Desai et al.2002), dat } \\
\text { rch data for medium t } \\
\text { ses of calculating the } \\
\text { the year of } 2014 \text { is d } \\
\text { the year of } 2015 \text { deri } \\
\text { ries (1583,034) was us } \\
\text { ses of calculating the } \\
\text { used. Related to the y } \\
\text { the year of } 2014 \text { deri } \\
\text { the year of } 2014 \text { deriv } \\
\text { the year of } 2015 \text { deri } \\
\text { the year of } 2013 \text { deri } \\
\text { est available data of th }\end{array}$ & $\begin{array}{l}\text { obtained from Euror } \\
\text { re missing for these } \\
\mathrm{g} \text { indicates has been } \\
\text { derived from World } \\
\text { of high and medium } \\
\text { nology exports could } \\
\text { l, the nearest availabl } \\
\text { ived from World Bank } \\
\text { d from International } \\
\text { d. } \\
\text { Al, the nearest availa } \\
\text { r of } 2013 \text { is derived fr } \\
d \text { from United Nation } \\
d \text { from International T } \\
\text { d from International } \\
d \text { from International } \\
\text { year } 2011 \text { was used. }\end{array}$ & $\begin{array}{l}\text { an Paten } \\
\text { ountries. } \\
\text { ed for th } \\
\text { nk Datak } \\
\text { chnolog } \\
\text { t be tra } \\
\text { data of y } \\
\text { atabase } \\
\text { ecomm } \\
\text { e data o } \\
\text { World } \\
\text { evolepm } \\
\text { ecommu } \\
\text { lecomm } \\
\text { ecomm } \\
\text { la data d }\end{array}$ & $\begin{array}{l}\text { ce } \\
\text { of data } \\
\text { ountries i } \\
\text { orts as pe } \\
\text { Related to } \\
014 \text { was } \\
\text { tion Unior } \\
\text { r } 2013 \text { wa } \\
\text { Database } \\
\text { rogramm } \\
\text { ion Union } \\
\text { tion Unio } \\
\text { tion Unior } \\
\text { d from } 20\end{array}$ & $\begin{array}{l}\text { these coun } \\
\text { e present st } \\
\text { tage of ma } \\
\text { year of } 201 \\
\text { for countrie } \\
\text { U). For purp } \\
\text { ed for cour } \\
\text { NDP). } \\
\text { J). } \\
\text { U). } \\
\text { U). } \\
\text {.uman }\end{array}$ & $\begin{array}{l}\text { enerally ind } \\
\text { elated to the } \\
\text { ured export } \\
\text { is derived fr } \\
\text { hich no dat } \\
\text { f calculating } \\
\text { and the we }\end{array}$ & $\begin{array}{l}\text { tle for } \\
2015 \text { c } \\
\text { d. How } \\
\text { Id Bank } \\
\text { vailable } \\
\text { the we } \\
\text { verage }\end{array}$ & $\begin{array}{l}\text { innovati } \\
\text { is derive } \\
\text { tabase. } \\
\text { ted ave } \\
\text { ue for OE }\end{array}$ & $\begin{array}{l}\text { occurring. } \\
\text { om World } \\
\text { extensive } \\
\text { value for } \\
\text { countries }\end{array}$ \\
\hline
\end{tabular}

